\section{Underfunding hits patents}

\section{London}

BRITISH investment in research and development is failing to match that of other nations and research output, measured by the number of patents granted in the United States, is suffering accordingly. Those are the key statistics buried in the 300-plus page Annual Review of Government Funded Research and Development, published by the UK Cabinet Office.

A total of $£ 10,300$ million was spent on research and development in the United Kingdom in 1988, representing an increase in real terms of 2.1 per cent from 1987. Thirty-seven per cent of funding came from government, 51 per cent from British industry and a small fraction from overseas.

But if the figures are converted to a proportion of the UK's gross domestic product (GDP), as is usual for international comparisons, British spending is seen to have stagnated at the 1985 level. In five other countries surveyed, research and development spending as a proportion of GDP is increasing (see figure), leaving Britain behind West Germany, Japan and the United States, but ahead of

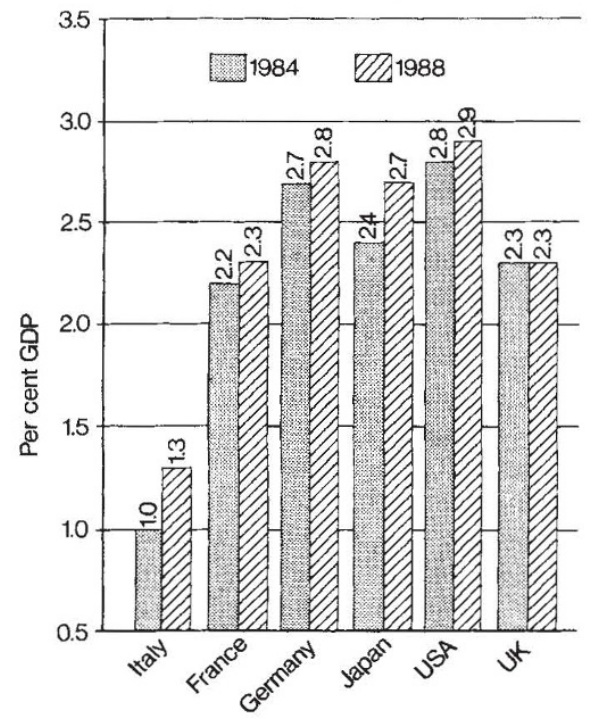

Gross domestic expenditure on research and development in six countries. West German and UK figures are for 1985 and 1988. Japanese figures are for 1984 and 1987

Italy and level with France. Even this analysis may exaggerate the British research and development effort: a recent report from the House of Lords Science and Technology Committee suggested that much of British defence research is not truly innovative and so does not conform to internationally accepted definitions of research and development (see Nature 345, 5; 3 May 1990).

For the first time, the Cabinet Office has included data on patents as a measure of the output of British research and development. The study looked at patents

granted in the United States in order to avoid bias when making comparisons with European countries and Japan.

Britain was granted 14 per cent more US patents per capita in 1984-88 than in 1979-83. But other countries did better. West Europe was up 23 per cent on average, led by West Germany with 28 per cent. The Japanese performance eclipses that of Europe, with 79 per cent more US patents per capita granted to Japan in $1984-88$ than in 1979-83.

The poor British performance is part of a long-term decline. In 1963-68 Britain was granted more US patents per capita than the West European average, with the Japanese rate less than a quarter that of the United Kingdom. But the UK rate for 1984-88, at 44.06 US patents per million population, was almost identical to the 1963-68 figure. In contrast, the West European average rose to 58.42 per milJAPAN'S SPACE PROGRAMME
Tokyo

JAPAN's next-generation H-II rocket will have less power than expected if and when it blasts off on its first flight in 1993.

The National Space Development Agency (NASDA) announced last week that the thrust specifications of the main engine of the rocket have had to be reduced so that the agency's engineers can meet the 1993 launch deadline.

The Japanese-made liquid fuel engine in the first stage of the $\mathrm{H}$-II has been plagued with problems ever since test firings began last year. In the first test runs, the turbine blades of the liquid hydrogen pump resonated and cracked, forcing a one-year delay in the first test launch of the rocket (see Nature 340, 253; 1989). In subsequent tests, the engine burst into flames.

After a series of 16 test firings between March and May this year, NASDA engineers thought they had their problems solved. But earlier this month the engine again caught fire during a test run.

This time the fire had an entirely different cause. M. Miyazawa, director of NASDA's propulsion systems group, says the fire began when hydrogen leaked from a small pipe feeding the liquid fuel to the ignition system of the engine. The pipe cracked when NASDA engineers deliberately made the engine vibrate to collect data necessary for the design of a vibration suppression device which will be incorporated into the engine.

Miyazawa stresses that under normal circumstances the engine would not have caught fire. But NASDA will now redesign three pipes in the engine, including

\title{
Rocket of falling ambitions
}

lion and Japan was granted 114.62 US patents per million of its population.

There are some seeds of comfort for the British scientific community. The number of academic research staff in UK universities has risen steadily over the 1980 s, from 6,309 in $1983-84$ to 8,413 in $1988-89$, and industrial research and development spending is at a record level, at $£ 6,900$ million in 1988.

Projections for UK spending up to 1992-93 may already have been overtaken by events. A decrease in the amount of civil research and development, relative to spending in the defence sector, is forecast. But the figures are based on the government's annual statement on public expenditure made last autumn, before the political upheavals in Eastern Europe raised the possiblity of a 'peace dividend'. A predicted decline in total research and development spending in real terms may also be found incorrect when the public expenditure statement is released in the autumn.

Peter Aldhous

the one that broke. And, more important, NASDA engineers now realize that they cannot build a reliable engine that meets the original thrust specification of 120 tons (in vacuum) by 1993 . So instead, the thrust will be reduced to 110 tons.

Naotaka Oki, director of the space development division of the Science and Technology Agency (STA) to which NASDA is affiliated, emphasizes that even with the reduced thrust the $\mathrm{H}$-II will still be able to meet its original goal and place a 2-ton payload into geostationary orbit. That will be possible because the power specifications of the solid fuel booster rockets and second-stage engine were increased last year. But the rocket will not be able to lift 2.2 tons as was hoped when the new specifications were announced, Miyazawa says.

When the rocket is used for the double launch of a geostationary meteorological satellite (GMS-5) and an unmanned space platform (SFU) in 1994, extra solid fuel boosters will be added to the first stage. But this is a "one-off case" and, despite reports to the contrary in the Japanese press, extra boosters will not be required for other launches, Oki says.

The H-II's first-stage liquid fuel engine, like that in the US Space Shuttle, uses a staged combustion cycle that provides higher performance than the gasgeneration cycle applied in other liquidfuel rockets such as Ariane and Delta. But this type of engine is notoriously difficult to develop. Miyazawa admits that, even with the reduced thrust specification, meeting the 1993 launch deadline will be "tight". 